\title{
Economic Recovery of Oil Trapped at Fan Margins Using High Angle Wells and Multiple Hydraulic Fractures
}

\author{
Quarterly Report \\ January 1 - March 31, 1997 \\ By:
Mike L. Laue
}

Work Performed Under Contract No.: DE-FC22-95BC14940

\author{
For \\ U.S. Department of Energy \\ Office of Fossil Energy \\ Federal Energy Technology Center \\ P.O. Box 880 \\ Morgantown, West Virginia 26507-0880
}

By

Atlantic Richfield Company

P. O. Box 147

Bakersfield, California 93302 


\section{Disclaimer}

This report was prepared as an account of work sponsored by an agency of the United States Government. Neither the United States Government nor any agency thereof, nor any of their employees, makes any warranty, express or implied, or assumes any legal liability or responsibility for the accuracy, completeness, or usefulness of any information, apparatus, product, or process disclosed, or represents that its use would not infringe privately owned rights. Reference herein to any specific commercial product, process, or service by trade

name, trademark, manufacturer, or otherwise does not necessarily constitute or imply its endorsement, recommendation, or favoring by the United States Government or any agency thereof. The views and opinions of authors expressed herein do not necessarily state or reflect those of the United States Government or any agency thereof. 
TITLE: ECONOMIC RECOVERY OF OIL TRAPPED AT FAN MARGINS USING HIGH ANGLE WELLS AND MULTIPLE HYDRAULIC FRACTURES

Cooperative Agreement No.: $\quad$ DE-FC22-95BC14940--06

Contractor Name and Address: $\quad$ Atlantic Richfield Co., P.O. Box 147, Bakersfield, California 93302

Date of Report: $\quad$ May 8, 1997

Award Date: $\quad$ September 28, 1995

Anticipated Completion Date: $\quad$ September 28, 2001

Government Award for

Current Fiscal Year: $\quad \$ 3,926,267$

Principal Investigator: Mike L. Laue, ARCO

Project Manager: $\quad$ Edith Allison, Bartlesville Project Office

Reporting Period: $\quad$ Jan. 1-Mar. 31, 1997

\section{Disclaimer}

This report was prepared as an account of work sponsored by an agency of the United States Government. Neither the United States Government nor any agency thereof, nor any of their employees, makes any warranty, express or implied, or assumes any legal liability or responsibility for the accuracy, completeness, or usefulness of any information, apparatus, product, or process disclosed, or represents that its use would not infringe privately owned rights. Reference herein to any specific commercial product, process, or service by trade name, trademark, manufacturer, or otherwise does not necessarily constitute or imply its endorsement, recommendation, or favoring by the United States Government or any agency thereof. The views and opinions of authors expressed herein do not necessarily state or reflect those of the United States Government or any agency thereof.

\section{Objective}

This project attempts to demonstrate the effectiveness of exploiting thin-layered, lowenergy deposits at the distal margin of a prograding turbidite complex through the use of hydraulically-fractured horizontal or high-angle wells. The combination of a horizontal or high-angle well and hydraulic fracturing will allow greater pay exposure than can be achieved with conventional vertical wells while maintaining vertical communication between thin interbedded layers and the wellbore.

A high-angle well will be drilled in the fan-margin portion of a slope-basin clastic reservoir and will be completed with multiple hydraulic-fracture treatments. Geologic modeling, reservoir characterization, and fine-grid reservoir simulation will be used to 
select the well location and orientation. Design parameters for the hydraulic-fracture treatments will be determined, in part, by fracturing an existing test well. Fracture azimuth will be predicted by passive seismic monitoring of a fracture-stimulation treatment in the test well using logging tools in an offset well.

\section{Summary of Technical Progress}

Drilling operations for the long radius, near-horizontal well have been completed. The well was cored in a small interval. Routine and advanced logs were run in the open hole section. Intermediate casing and production liners were run and cemented in place.

Routine and special core tests are in progress. Preliminary log analysis has been completed. Log results are being validated with core data and with log-core relationships established during Budget Period One. The completion program is being designed for the well, which is planned for two hydraulic fracture treatments. Preliminary sizing of electric submersible lift equipment (ESP) has been completed.

\section{Drilling Progress}

\section{Directional Results}

The project well, Yowlumne Unit B 91X-3, was drilled as a long radius, nearhorizontal well. The well penetrated the Yowlumne sand, an Upper Miocene Stevens sand equivalent, in the distal fan margin in the northeast area of the field (Fig 1). It was drilled in a predominately westerly direction towards the interior of the field, in the direction of improving rock quality.

Kickoff point in the $12-1 / 4$ in. hole was at 11,471 ft. A steerable drilling assembly consisting of bent subs and mud motors was used to build angle at approximately $7^{\circ}$ per $100 \mathrm{ft}$ while drilling an 8-1/2 in. hole. The top of the Yowlumne sand was encountered at $12,959 \mathrm{ft}$, or $12,329 \mathrm{ft}$ TVD $(-11,810 \mathrm{ft}$ subsea). The well reached a total depth (TD) of $14,300 \mathrm{ft}$, or $12,515 \mathrm{ft}$ TVD $(-11,996 \mathrm{ft}$ subsea). The wellbore is exposed to $1341 \mathrm{ft}$ of Stevens sand at an average angle of $84^{\circ}$ from vertical. The bottomhole location is $253 \mathrm{ft}$ north and $2237 \mathrm{ft}$ west of the surface location (2248 ft. of closure). Figure 2 is a cross sectional view of the well path.

\section{Coring Operations}

Thirty $\mathrm{ft}$ of 4-1/2 in. core was cut and recovered from 12,991 to $13,021 \mathrm{ft}$. The core was taken near the top of the Yolwumne sand, in near-horizontal hole $\left(83^{\circ}\right)$. Pulling the drill pipe and core barrel was extremely difficult in the high angle hole because of sloughing formation. Therefore, no additional core was taken, although two more $20 \mathrm{ft}$ cores were planned.

\section{$\underline{\text { Logging Operations }}$}

Drillpipe-conveyed logs were run in the $2858 \mathrm{ft}$ of open hole below the 9-5/8 in. intermediate casing. Conventional logging tools were run consisting of litho density (LDL) 
and compensated neutron logs $(\mathrm{CNL})$ to obtain porosity data, and a dual induction log (IDPH) to obtain resistivity data.

Three advanced logging tools were also run. A high-resolution magnetic resonance tool (CMR) was run to infer producibility, flowing phases, permeability, and water cut. A dipole shear sonic imaging tool (DSI) was run to obtain mechanical properties to be used for designing hydraulic fracture treatments, such as stress values, Young's Modulus, and Poisson's Ratio. In addition, the travel time data could be used to compute sonic porosities. Finally, a fullbore formation micro imaging tool (FMI) was run to obtain a "visual image" of the formation face, which could be used to identify natural fractures and/or faults, if any. Unfortunately, the FMI tool failed, and because of hole conditions, the wait time for a backup tool was prohibitive. Thus, an FMI log was not obtained.

\section{$\underline{\text { Casing Data }}$}

Thirteen and three-eighths in. surface casing was cemented in place at a depth of $2522 \mathrm{ft}$. The 12-1/4 in. vertical hole section was cased with 9-5/8", 47 and $53.5 \mathrm{lbs} / \mathrm{ft}, \mathrm{P}-110$ intermediate casing and cemented in place at 11,442 ft. It had been planned to set the intermediate string near the top of the Yowlumne sand in a tangent section of the highangle hole to maximize pump-setting depth. However, sloughing shales necessitated setting the intermediate casing approximately $1200 \mathrm{ft}$ short of plans. The casing is large enough to produce the well with an electric submersible pump (ESP) hung off a "Y" offset tool. The "Y" offset tool will permit production logging while the well is producing.

A 7 in., $32 \mathrm{lbs} / \mathrm{ft}$., P-110 production liner had been planned to be run to TD. However, the liner became stuck at $13,424 \mathrm{ft}$. The liner was cemented in place without pipe rotation and reciprocation. The remaining $876 \mathrm{ft}$ of open hole was cased with a 5 in., 23.2 $\mathrm{lbs} / \mathrm{ft} ., \mathrm{P}-110$ liner and cemented in place.

The intermediate casing and production liners were designed to withstand expected bottomhole pressures higher than 16,000 psi during hydraulic-fracture treatments.

\section{Log and Core Analysis}

\section{$\underline{\log \text { Analysis }}$}

The Yowlumne sand in the distal fan margin is shaly, as indicated by a crossplot of density porosity vs. neutron porosity for the project well (Fig. 3). To be consistent with other wells in the field, log-derived porosities were based upon sonic data. Sonic porosities were reduced for shaliness using gamma ray and neutron porosity data to calculate effective porosities.

Average rock properties for each sand interval are shown in Tables 1 and 2. These values are considered preliminary until log calculations are validated with core data and CMR log data. 
Table 1 gives average properties for net sand based upon the following cutoffs:

1) Shale volume $(\mathrm{Vsh})<30 \%$

2) Effective porosity ( $\phi$ eff) $>8 \%$

All net sand with water saturations less than $40 \%$ was considered net pay. Average properties for net pay are shown in Table 2.

Net sand and net pay cutoffs were derived from geologic and reservoir modeling during Budget Period One (BP1). Permeabilities were calculated based upon a log porositycore permeability relationship established during BP1.

Processing of the CMR log is in progress. It is hoped that reliable information can be inferred regarding permeability, producibility, and fractional flow of oil and water. These values will then be reconciled with core data and the log-core relationships established during BP1.

The DSI log is being processed for mechanical properties to be used for designing hydraulic fracture treatments such as stress values, Young's Modulus, and Poisson's Ratio.

\section{Core Analysis}

Routine and special core analysis is in progress on samples from the $30 \mathrm{ft}$ core cut in the project well. Routine porosity, saturation, and permeability measurements have been completed. Preliminary results have been received from relative permeability, capillary pressure, and mechanical properties tests.

Many of the samples used in the stressed mechanical properties tests indicate an approximate east-west maximum principal stress orientation. This agrees with BP1 microseismic logging results of the hydraulic fracture treatment on the test well (Yowlumne Unit B 84-32). It also agrees with borehole breakout data from Yowlumne Unit B 57X-34, a north offset well to the project well. Therefore, vertical fractures established during the hydraulic fracture treatments in the project well are expected to propagate approximately in the same direction as the azimuth of the well. This is the preferred frac azimuth because of existing waterflood fronts and proximity to offset wells.

Results of core analyses will be reconciled with log data from the project well and with log-core relationships established during BP1. In addition, substantial thin-section work will be performed.

\section{Completion Design}

The completion design is in progress. Log analysis indicates that some intervals have been swept by the waterflood (as expected). Current plans are to complete the well with one and possibly two hydraulic fracture treatments.

Fracture treatments are being designed with the expectation that the fracs will be oriented in the direction of the wellbore. Relatively short fracture half-lengths of 150 to 200 
$\mathrm{ft}$ are being planned for the possibility that the fracs instead orient orthogonal to the wellbore. This should minimize undesirable changes in areal sweep.

\section{Artificial Lift Design}

The well will be produced with an ESP to maximize drawdown. The well is expected to produce at rates up to $3000 \mathrm{BPD}$ with a bottom hole producing pressure of 1000 to 1500 psi. There is a wide variation of reservoir pressure across reservoir layers, and maximizing drawdown is necessary to promote production from lower pressure, higher oil cut intervals.

The ESP will be set in the 9-5/8 in. casing in the vertical section of the hole. It will be hung off a "Y" offset tool so that production logging and pressure data collection can take place while the well is on production.

\section{Technology Transfer}

Two technology transfer activities took place during the first quarter of 1997 . On February 4, 1997, Dr. Mike Clark conducted a field trip to witness drilling operations for the project well. A petroleum geology class (instructor Dr. James Boles) from the University of California, Santa Barbara participated in the field trip.

On March 2, 1997, Dr. Clark gave a presentation and hosted a poster session at the Department of Energy Class Program Workshop, Fourth International Reservoir Characterization Technical Conference, Houston, Texas. His paper was published in softbound notes handed out at the workshop (pages 49-63). In addition, this paper will be published by the AAPG in hardbound symposium proceedings. 
Table 1

* Net Sand Properties

\begin{tabular}{crrrrrrr}
\hline Sand & Gross Sand, ft & Net Sand, ft & Net-to-Gross & Porosity, \% & Wat. Sat., \% & Perm., md & Water Cut, \% \\
\hline A & 110 & 86 & 0.78 & 11.3 & 44.9 & 0.5 \\
B & 367 & 300 & 0.82 & 11.6 & 37.7 & 0.9 \\
C & 303 & 241 & 0.80 & 11.3 & 40.1 & 38 \\
D & 389 & 364 & 0.94 & 11.7 & 65.4 & 1.3 \\
** E & 105 & 95 & 0.90 & 12.3 & 75.9 & 1.5 \\
Tot. / Avg. & 1274 & 1085 & 0.85 & 11.6 & 51.4 & 1.3 & 1.2 \\
\hline
\end{tabular}

* Footages based on measured depths.

** Sand E not fully penetrated. 


\section{Table 2}

* Net Pay Properties

\begin{tabular}{crrrrrrr}
\hline Sand & Gross Sand, ft & Net Sand, ft & Net Pay, ft & Porosity, \% & Wat. Sat., \% & Perm., md & Water Cut, \% \\
\hline A & 110 & 86 & 24 & 12.8 & 36.7 & 1.3 \\
B & 367 & 300 & 188 & 12.3 & 33.1 & 1.2 \\
C & 303 & 241 & 125 & 12.6 & 33.5 & 2.3 \\
D & 389 & 364 & 38 & 12.8 & 34.6 & 15 \\
** E & 105 & 95 & 0 & - & - & 15 \\
Tot. / Avg. & 1274 & 1085 & 374 & 12.5 & 33.6 & - \\
\hline
\end{tabular}

* Footages based on measured depths.

** Sand E not fully penetrated. 


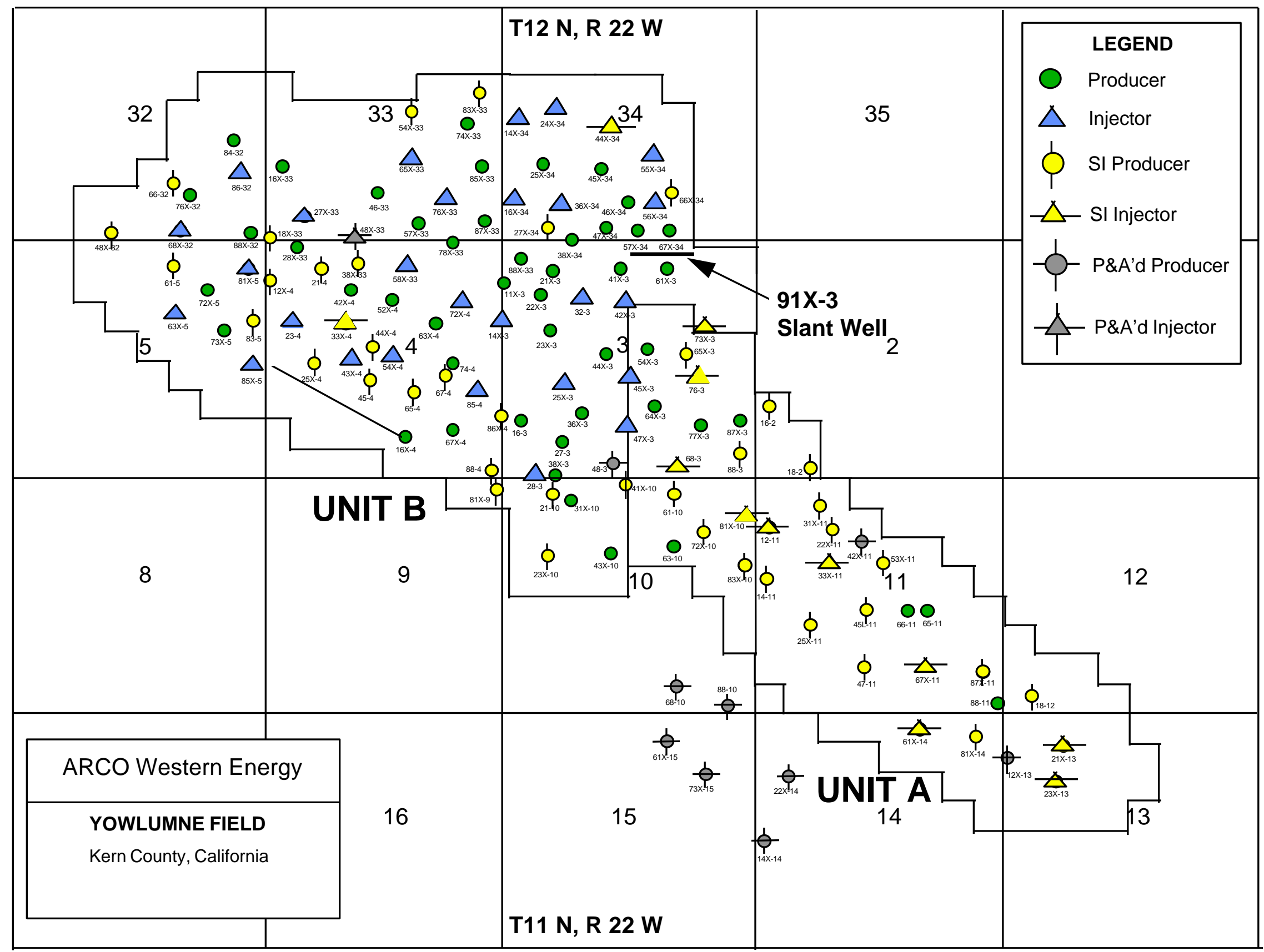

Figure 1. Base map of Yowlumne field showing path of near-horizontal well. 


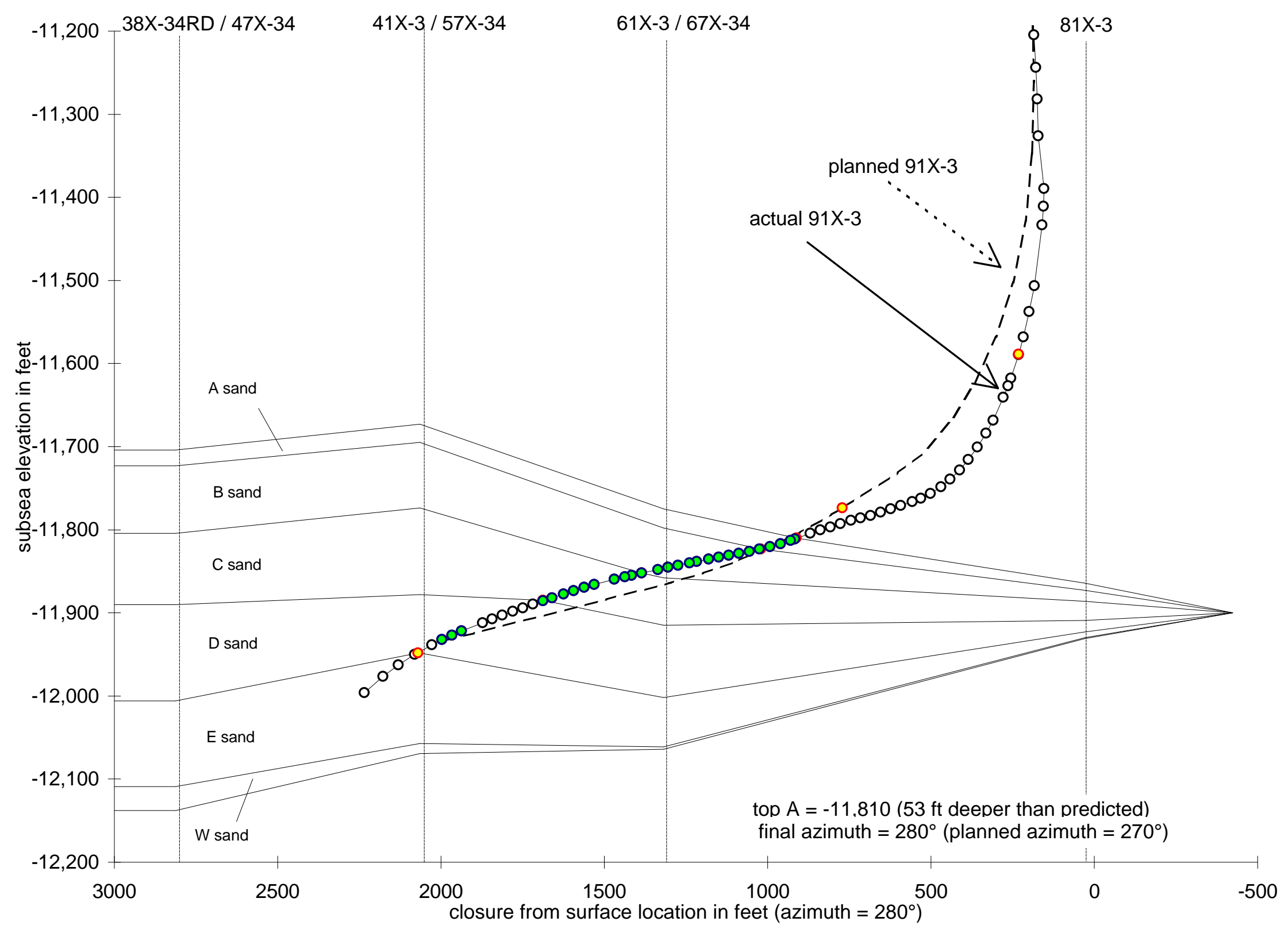

Figure 2. Actual well path of Yowlumne Unit B 91X-3. Offset well locations are projected into the same vertical plane as the horizontal well. 


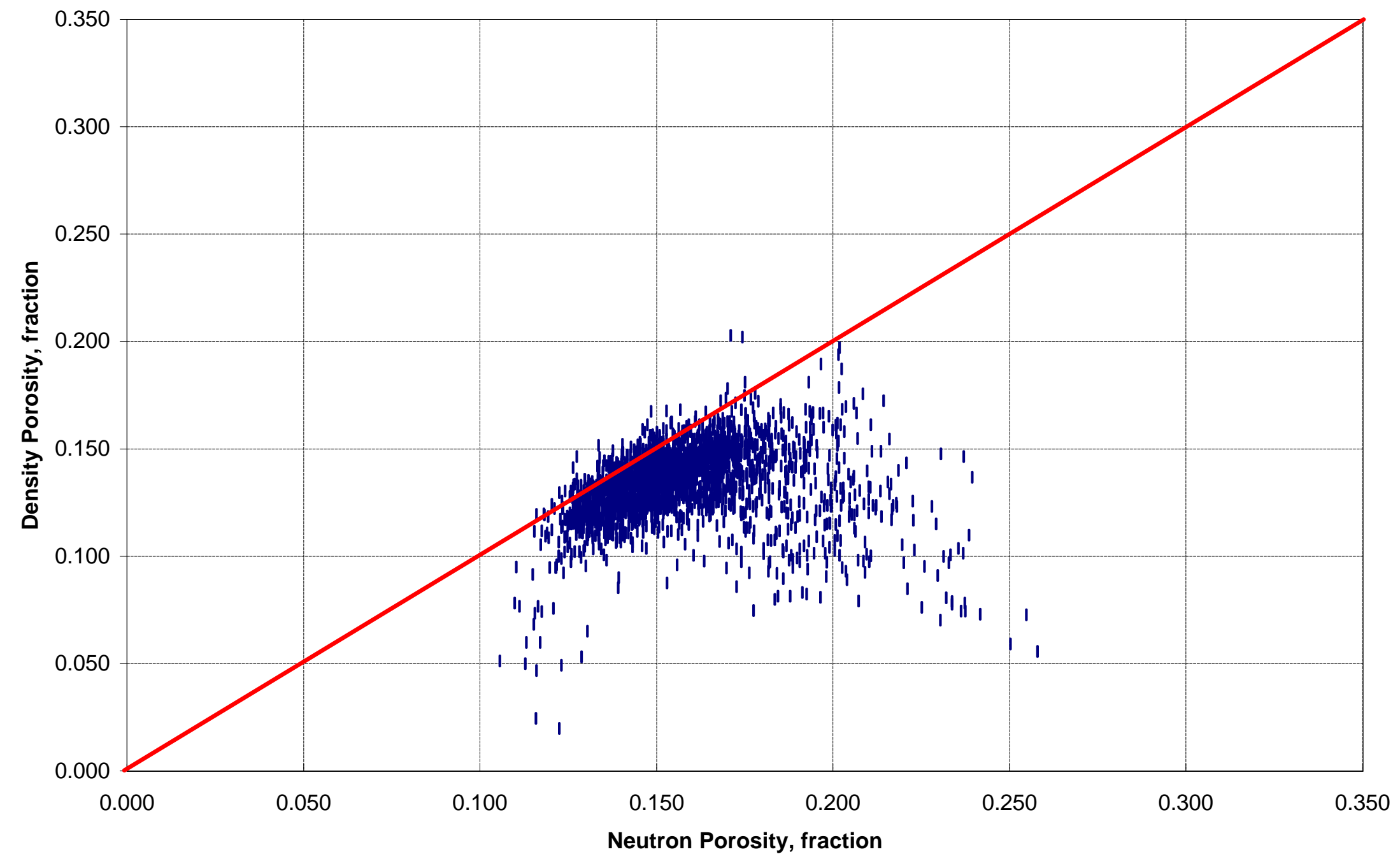

Figure 3. Crossplot of density porosity vs. neutron porosity indicating a shaly Yowlumne sand. 